九州大学学術情報リポジトリ

Kyushu University Institutional Repository

\title{
The Role of Laccase from White Rot Fungi to Stress Conditions
}

Cho, Nam-Seok

Wood and Paper Science, Chungbuk National University

Wi lkolazka, Anna Jarosz

Department of Biochemistry, Maria Curie-Sklodowska University

Staszczak, Magdalena

Department of Biochemistry, Maria Curie-Sklodowska University

Cho, Hee-Yeon

Molecular Microbiology and Immunology, Keck School of Medicine, University of Southern California

他

https://doi.org/10.5109/14041

出版情報 : 九州大学大学院農学研究院紀要. 54 (1)，pp.81-83，2009-02-27. Faculty of Agriculture， Kyushu University

バージョン:

権利関係: 


\title{
The Role of Laccase from White Rot Fungi to Stress Conditions
}

\author{
Nam-Seok CHO ${ }^{1}$, Anna Jarosz WILKOLAZKA², Magdalena STASZCZAK ${ }^{2}$, \\ Hee-Yeon $\mathrm{CHO}^{3}$ and Shoji OHGA*
}

\author{
Laboratory of Forest Resources Management, Division of Forest Ecosphere Management, \\ Department of Forest and Forest Products Sciences, Kyushu University, \\ Sasaguri, Fukuoka 811-2415, Japan \\ (Received November 25, 2008 and accepted December 5, 2008)
}

\begin{abstract}
This study was performed in order to investigate the effect of selected xenobiotic compounds, such as different stress factors, $\mathrm{Cd}(\mathrm{II}), \mathrm{Zn}$ (II), $\mathrm{Cu}$ (II) and $\mathrm{Mn}$ (II) ions or some pro-oxidants: menadione, paraquat and hydrogen peroxide, on laccase activity with some white-rot fungi. Changes in laccase activity in the presence of natural fungicidals, the saponins from Medicago sativa roots, were also examined. The introduction of both metal ions and some pro-oxidants into the medium enhanced a multiple increase in extracellular laccase activity for the two fungal strains, Trametes versicolor and Abortiporus biennis. An notable increase in laccase level had already appeared in the 36 hour by the treatment with oxidative stress factors (menadion, paraquat and hydrogen peroxide), anti-fungal substance saponines as well as metal ions. The enhanced activity of laccase under heavy metal ions presence also suggests its important role in the fungal adaptation processes, what could be utilized to heavy metals containing waste materials. These strains of white-rot fungi could also be used to remove heavy metals from aqueous solutions by adsorbing the metals on mycelium and to biodegrade various organic xenobiotics by extracellular laccase. The presence of harmful compounds in the medium which might appear lethal for other organisms arouses detoxification abilities of this fungal group by increasing extracellular discharge of ligninolytic enzymes, in particular laccase. This offers extremely large possibilities for biotechnological use of white-rot fungi.
\end{abstract}

\section{INTRODUCTION}

During the whole development cycle living organisms are subject to different kind of stress conditions, such as changes in temperature, UV radiation or various xenobiotic compounds appearing in the environment (Jamieson, 1995; Koga and Takumi, 1995). Consequently they have developed during their evolution a range of effective enzymatic or non-enzymatic systems of response to stress factors (Mager and Kruijff, 1995; Ruis and Schiller, 1995). Basidiomycetes species, presented in this report, are considered to be a very interesting but little known group of fungi. Given their exceptional adjustment abilities, they can accommodate to detrimental conditions of the environment where they continue to act as natural lignocellulose destroyers (Tuor et al., 1995).

Our experiments imply a distinct influence that various stress factors exert upon the activity of laccase the oxidoreductase taking part in lignin depolymerization (Thurston, 1994; Collins and Dobson, 1997). This enzyme, belonging to polyphenolic oxidases, can be used in biotechnological processes, for instance whitening wood pulp, decomposition of different kinds of biopolymers or detoxification of environmental pollut-

Wood and Paper Science, Chungbuk National University, Cheongju 361-763, Korea

${ }^{2}$ Department of Biochemistry, Maria Curie-Sklodowska University, Plac M. Curie-Sklodowskiej 3, Pl 20-031 Lublin, Poland

Molecular Microbiology and Immunology, Keck School of Medicine, University of Southern California, Los Angeles, CA 90089, USA

* Corresponding author (E-mail: ohga@forest.kyushu-u.ac.jp) ants (Monteiro and Carvalho, 1998; D'Annibale et al., 1999). Laccase oxidizes a number of aromatic hydrogen donors forming free phenoxy radicals and catalyzes reactions of decarboxylation and demethylation of phenolic and methoxyphenolic acids (Thurston, 1994; Potthast et al., 1995). Laccases are produced by the majority of white-rot fungi described to date as well as by other types of fungi and by plants (Aramayo and Timberlake, 1990; Wahleithner et al., 1996). There are many reports concerning influence of a number of substances on the activity of extracellular laccase in various white-rot fungi. These data were collected in Table 1.

This experiment was carried out to compare the effect of selected xenobiotic compounds on laccase activity with some white-rot fungi. Trametes versicolor and Abortiporus biennis cultures were grown in liquid mineral media, and subjected to different stress factors such as $\mathrm{Cd}(\mathrm{II}), \mathrm{Zn}(\mathrm{II}), \mathrm{Cu}(\mathrm{II})$ and $\mathrm{Mn}$ (II) ions or some pro-oxidants: menadione, paraquat and hydrogen peroxide. Changes in laccase activity in the presence of natural fungicides, such as saponins from Medicago sativa roots, were also examined.

\section{MATERIALS AND METHODS}

\section{Fungal material and culture conditions}

White-rot basidiomycetes - Abortiporus biennis (Bull.ex Fr.) Sing and Trametes versicolor (L. ex Fr.) Pil were obtained from the culture collection of the Department of Biochemistry, Maria Curie-Sklodowska University of Lublin, Poland. Fungi were maintained on $2 \%(\mathrm{wt} / \mathrm{vol})$ malt agar slants. For inoculation the fungal agar plugs $\left(c a .0 .5 \mathrm{~cm}^{2}\right)$ were cut and grown in a 
Table 1. The induction of extracellular laccase in the culture of selected strains of Basidiomycetes

\begin{tabular}{|c|c|c|c|}
\hline Strain & $\begin{array}{l}\text { Compounds } \\
\text { (concentration) }\end{array}$ & $\begin{array}{l}\text { Increase of laccase activity } \\
\text { to control cultures }\end{array}$ & References \\
\hline Trametes versicolor & $\mathrm{CuSO}_{4}(400 \mu \mathrm{M})$ & $18 \mathrm{x}$ & Collins et al., 1997 \\
\hline Trametes versicolor & $\mathrm{NH}_{4}+(60 \mathrm{mM})$ & $15 \mathrm{x}$ & Collins et al., 1997 \\
\hline Trametes versicolor & 2,5-xylidine $(500 \mu \mathrm{M})$ & $40 \mathrm{x}$ & Collins et al., 1997 \\
\hline Trametes versicolor & $\begin{array}{l}\text { 1-hydroxybenzotriazole } \\
(500 \mu \mathrm{M})\end{array}$ & $25 \mathrm{x}$ & Collins et al., 1997 \\
\hline Phanerochaete chrysosporium & $\mathrm{CuSO}_{4}(400 \mu \mathrm{M})$ & $8 \mathrm{x}$ & Dittmer et al., 1997 \\
\hline Pycnoporus cinnabarinus & 2,5-xylidyne $(10 \mu \mathrm{M})$ & $9 \mathrm{x}$ & Eggert et al., 1996 \\
\hline Pycnoporus cinnabarinus & lignosulfonate (1\%) & $3 \mathrm{x}$ & Eggert et al., 1996 \\
\hline Pycnoporus cinnabarinus & veratric alcohol (1 mM) & $2 \mathrm{x}$ & Eggert et al., 1996 \\
\hline Pleurotus eryngii & alkalic lignin $(400 \mu \mathrm{M})$ & $6 \mathrm{x}$ & Munoz et al., 1997 \\
\hline Pleurotus eryngii & vanilic acid $(400 \mu \mathrm{M})$ & $4 \mathrm{x}$ & Munoz et al., 1997 \\
\hline Pleurotus eryngii & veratric acid $(400 \mu \mathrm{M})$ & $3 \mathrm{x}$ & Munoz et al., 1997 \\
\hline
\end{tabular}

basal medium (Lindeberg, 1952) for A. biennis and for T. versicolor (Fahreus and Rainhammar, 1967). Culture medium contained glucose as the main source of carbon, L-asparagine as the main source of nitrogen and trace element's solution. The cultures were grown in static flasks at $25^{\circ} \mathrm{C}$ till the mycelium colonized the whole surface of the liquid. The mycelial mats were collected and homogenized in a Warning blender. The stationary cultures, after inoculation with $4 \%$ (v/v) of the homogenate, were incubated at $25^{\circ} \mathrm{C}$ in $25 \mathrm{ml}$ Erlenmayer flasks containing $10 \mathrm{ml}$ medium (Fahreus and Rainhammar, 1967). The extracellular medium was separated from mycelium by filtration through Miracloth (Calbiochem). All measurements were recorded using extracellular cultures of 5th day after addition of heavy metals, parquat, menadione, hydrogen peroxide and saponins.

\section{Stress conditions}

The 10-day-old cultures of A. biennis and T. versicolor were treated with different kinds of stress factors such as Cd(II), $\mathrm{Cu}$ (II), Zn(II) and Mn(II) ions, and to selected pro-oxidants: menadione, paraquat and hydrogen peroxide. Additionally, changes in laccase activity in the presence of natural fungicidals, the saponins Medicago sativa roots, were examined.

\section{Laccase assays}

Laccase activity was measured by monitoring the oxidation of syringaldazine (Leonowicz and Grzywnowicz, 1981). The reaction mixture contained $0.025 \mathrm{mM}$ syringaldazine, $50 \mathrm{mM}$ citrate-phosphate buffer pH 5.2 and enzyme. The oxidation of syringaldazine was monitored by the increase in the $A_{520}\left(\varepsilon_{520}=\right.$ $\left.6.5 \times 10^{4} \mathrm{M}^{-1} \mathrm{~cm}^{-1}\right)$.

\section{Determination of protein}

Protein concentrations were determined by using Bradford reagent and bovine serum albumin as the standard (Bradford, 1976).

\section{RESULTS AND DISCUSSION}

Our investigations showed the introduction of both metal ions and some pro-oxidants into the medium to enhance a multiple increase in extracellular laccase activity for the two fungal strains. An notable increase in laccase level had already appeared in the 36th hour following the treatment with oxidative stress factors (menadion, paraquat and hydrogen peroxide), anti-fungal substance saponines as well as metal ions (Tables 2 and 3). The increased laccase level initiated by high temperature was described by Fink-Boots et al. (1999) in the cultures of selected strains of Basidiomycetes as the consequence of adaptation to changes of environmental temperature conditions. The enhanced activity of laccase under heavy metal ions presence (Table 2) also suggests its important role in the fungal adaptation processes, what could be utilized to heavy metals containing waste materials.

These strains of white-rot fungi could be used to remove heavy metals from aqueous solutions by adsorbing the metals on mycelium and to biodegrade various

Table 2. The influence of various divalent cations on the activity of extracellular laccase in the cultures of Abortiporus biennis and Trametes versicolor

\begin{tabular}{ccc}
\hline Heavy metals & Abortiporus biennis & Trametes versicolor \\
\hline & & \\
Cd (II) & $14.5 \pm 0.8$ & $5.8 \pm 1.2$ \\
Zn (II) & $3.8 \pm 0.9$ & $8.2 \pm 1.4$ \\
Cu (II) & $6.7 \pm 1.2$ & $7.4 \pm 0.8$ \\
Mn (II) & $2.2 \pm 0.5$ & $2.1 \pm 0.4$
\end{tabular}

Heavy metals were added to 10-day-old cultures. Data present activities of laccase from metal ions - amended cultures in comparison to control cultures. The laccase activities in control cultures were taken as 1 .

Table 3. The influence of various inducers on the activity of extracellular laccase in the cultures of Abortiporus biennis and Trametes versicolor

Type of substance Abortiporus biennis Trametes versicolor

\begin{tabular}{lrr}
\hline & $8.5 \pm 0.7$ & $10.2 \pm 1.7$ \\
menadione & $4.9 \pm 0.5$ & $7.9 \pm 1.2$ \\
paraquat & $6.1 \pm 0.8$ & $3.9 \pm 0.4$ \\
hydrogen peroxide & $4.2 \pm 0.5$ & $12.1 \pm 1.8$ \\
saponins &
\end{tabular}

Substances were added to 10-day-old cultures. Data present activities of laccase from substances - amended. 
organic xenobiotics by extracellular laccase. This enzyme reduces oxygen to water and stimultaneously performs an electron oxidation of many aromatic substrates (polyphenols, methoxy-substituted monophenols, and aromatic amines) but in the presence of mediators, the substrate range of laccase can be extended (Burbonnaise et al., 1997). The different degree of degradation activity of white-rot fungi with respect to lignin and other organic compounds depends on the environmental conditions and the fungal species. Such an increased activity of laccase entails participation of the enzyme in response mechanism to external stress factors. This experiments have confirmed an extremely strong resistance of white-rot fungi to detrimental changes in the external environment. The presence of harmful compounds in the medium which might appear lethal for other organisms arouses detoxification abilities of this fungal group by increasing extracellular discharge of ligninolytic enzymes, in this case laccase. Even though our research does not conclusively explain the molecular aspects of laccase activity as a responce to various stress factors, the above sequence of reactions justifies describing this enzyme as important in fungal cell protection against stress. This offers extremely large possibilities for biotechnological use of white-rot fungi.

\section{ACKNOWLEDGEMENTS}

Parts of this work was carried out with the supports of the European Community (the RTD5 EC proposal No ICA2-1999-10027 - Acronym PUBLIER) and KBN (6 P04A 030 17), and the International Cooperative Research Projects(1998-010-92) of Korea Research Foundation.

\section{REFERENCES}

Aramayo, R. and W. E. Timberlake 1990 Sequence and molecular structure of the Aspergillus nidulansy A (laccase I) gene. Nucleic Acids Res., 18: 3415-3420

Bradford, M. M. 1976 A rapid and sensitive method for the quantitation of microgram quantities of proteins utilizing the principle of protein-dye binding. Anal. Biochem., 72: 248-254

Burbonnaise, R., M. G. Paice, B. Freiermuth, E. Bodie and S.
Borneman 1997 Reactivities of various mediators and laccases with kraft pulp and lignin model compounds. Appl. Environ. Microbiol., 63: 4627-4632

Collins, P. J. and A. D. W. Dobson 1997 Regulation of laccase gene transcription in Trametes versicolor. Appl. Environ. Microbiol., 63: 3444-3450

D’Annibale, A., S. R. Stazi, V. D. Vinciguerra, E. Mattia and G. G. Sermanni 1999 Characterization of immobilized laccase from Lentinula edodes and its use in olive-mill wastewater treatment. Proc. Biochem., 34: 697-706

Dittmer, J. K., N. J. Patel, S. W. Dhawale and S. S. Dhawale 1997 Production of multiple laccase isoforms by Phanerochaete chrysosporium grown under nutrient sufficiency. FEMS Microbiol. Lett., 149: 65-70

Eggert, C., U. Temp and K. E. L. Eriksson 1996 The ligninolytic system of the white-rot fungus Pycnoporus cinnabarinus: purification and characterization of the laccase. Appl. Environ. Microbiol., 62: 1151-1158

Fahreus, G. and B. Rainhammar 1967 Large-scale production and purification of laccase from the fungus Polyporus versicolor and some properties of laccase. Acta Chem. Scand., 21: $2367-2378$

Fink-Boots, M., E. Malarczyk and A. Leonowicz 1999 Increased enzymatic activities and levels of superoxide anion and phenolic compounds in cultures of Basidiomycetes after temperature stress. Acta Biotechnol., 19: 319-330

Leonowicz, A. and K. Grzywnowicz 1981 Quantitative estimation of laccase forms in some white-rot fungi using syringaldazine as a substarte. Enzyme Microbiol. Technol., 3: 55-58

Lindeberg, G. and G. Holm 1952 Occurrence of tyrosinase and laccase in fruit bodies of mycelia of some hymenomycetes. Physiol. Plant., 5: 100-114

Monteiro, M. C. and M. E. A. Carvalho 1998 Pulp bleaching using laccase from Trametes versicolor under high temperature and alkaline conditions. Appl. Biochem. Biotechnol., 70: 983-993

Munoz, C., F. Guillen, A. T. Martinez and M. J. Martinez 1997 Induction and characterization of laccase in the ligninolytic fungus Pleurotus eryngii. Curr. Microbiol., 34: 1-5

Potthast, A. T., T. Rosenau, C. L. Chen and J. S. Gratzl 1995 Selective enzymatic oxidation of aromatic methyl groups to aldehydes. J. Org. Chem., 60: 4320-4321

Thurston, C. F. 1994 The structure and function of fungal laccases. Microbiology., 140: 19-26

Tuor, U., K. Winterhalter and A. Fiechter 1995 Enzymes of white-rot fungi involved in lignin degradation and ecological determinants for wood decay. J. Biotechnol., 41: 1-17

Wahleithner, J. A., F. Xu, K. M. Brown, E. J. Golightly, T. Halker, S Kauppinen, A. Peterson and P. Schneider 1996 The identification and characterization of four laccases from the plant pathogenic fungus Rhizoctonia solani. Curr. Genet., 29: 395-403 